\title{
Retinoidal Dienamides and Related Aromatic Amides. Replacement of the 9-Ene Structure of Retinoic Acid with a trans- or cis-Amide Group
}

\author{
Hideo Shimasaki, Hiroyuki Kagechika, Hiroshi Fukasawa, Emiko Kawachi, and \\ Koichi SHUDO* \\ Faculty of Pharmaceutical Sciences, University of Tokyo, 7-3-1 Hongo, Bunkyo-ku, Tokyo 113, Japan. \\ Received September 7, 1994; accepted October 11, 1994
}

\begin{abstract}
Several retinoid candidates which possess an amide bond at the position corresponding to the 9-ene part of retinoic acid (1) were synthesized and their conformations and biological activities were investigated. $N$-(Methoxycarbonyl)dienamines, prepared by the rearrangement of dienoic acid azides trapped by methanol, were condensed with acid chlorides, followed by removal of the methoxycarbonyl group and hydrolysis of the ester group to afford the secondary dienamides, $N$-(2,6,6-trimethyl-1-cyclohexen-1-yl)muconamic acid (7a), 5-[[3-(2,6,6-trimethyl-1cyclohexen-1-yl)-2-propenoyl]amino]-2,4-pentadienoic acid (8a), and 4-[N-[2-(2,6,6-trimethyl-1-cyclohexen-1yl)ethenyl]carbamoyl]benzoic acid (26a). The tertiary amide derivatives were also prepared by $N$-methylation of the secondary amides. NMR studies indicated that the secondary dienamides exist predominantly in trans-amide form in solution, like the potent retinoidal aromatic amide, 4-[(5,6,7,8-tetrahydro-5,5,8,8-tetramethyl-2-naphthalenyl)carbamoyl]benzoic acid (Am80). $N$-Methylation of the secondary amides resulted in cis-amide preference in solution. The biological activities of these amides were examined in terms of the differentiation-inducing activity towards human promyelocytic leukemia cell line HL-60.
\end{abstract}

Keywords retinoic acid; retinoid; dienamide; conformation; cell differentiation

Retinoic acid (all-trans, 1) and its biological isosters, so-called retinoids, are involved in the control of cellular differentiation and proliferation, ${ }^{1,2)}$ and also in embryonic development. ${ }^{3)}$ A wide variety of biological responses of retinoids result from binding with specific retinoic acid receptors (RARs), ${ }^{4,5)}$ which belong to the steroid/thyroid nuclear receptor superfamily. ${ }^{6}$ Binding abilities of retinoic acid (1) and synthetic retinoids to RARs correlate well with their physiological activities, and the complexes regulate gene expressions. ${ }^{7)}$ Recently, another set of nuclear receptors for retinoids, RXRs, was reported. ${ }^{8)}$ Although RXRs cannot bind to retinoic acid (1) and some potent synthetic analogs, they bind to 9-cis-retinoic acid (2), and their complexes have also been proved to participate in the regulation of gene transcriptions.

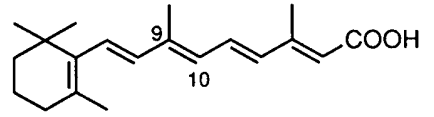

1

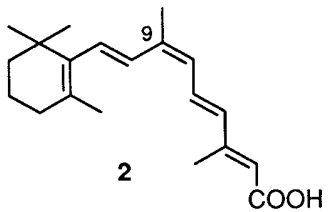

The physiological effects of retinoids have led to their utilization for chemotherapy in the fields of dermatology and oncology. Some of them, such as retinoic acid (1) or etretinate, have been recognized to be useful for the treatment of leukemia ${ }^{9)}$ or psoriasis, ${ }^{10}$ ) although they have significant side effects, due in part to their high hydrophobicity. We have reported potent retinoidal activities of various benzoic acid derivatives, named retinobenzoic acids. ${ }^{11)}$ Among them, two types of aromatic amides, 4-[(5,6,7,8-tetrahydro-5,5,8,8-tetramethyl2-naphthalenyl)carbamoyl]benzoic acid (Am80, 3) and 4[(5,6,7,8-tetrahydro-5,5,8,8-tetramethyl-2-naphthalenyl)carboxamido]benzoic acid (Am580, 4), exhibited higher activities than retinoic acid (1) in various assay systems. ${ }^{12-14)}$ Furthermore, these amide compounds have several unique features as retinoids. First, Am80 (3) binds strongly to two subtypes of $\operatorname{RARs}, \operatorname{RAR} \alpha$ and $\operatorname{RAR} \beta$, but not to $\operatorname{RAR} \gamma{ }^{1{ }^{15,16)}}$ Retinoids that can bind selectively to the receptor subtypes should be useful as tools for the elucidation of retinoidal actions and also for clinical applications, because they should exhibit only a part of the wide variety of the biological responses of retinoids. ${ }^{15-17)}$ Second, they seem to possess better therapeutic indexes (higher activity and lower toxicity) than conventional retinoids because of the receptor selectivity. ${ }^{18)}$ Am80 (3) and Am580 (4) possess a polar amide group as the linking group between the two aromatic moieties and therefore are expected to exhibit different physicochemical properties from those of the hydrophobic retinoids. Indeed, the clearance of Am80 from animals was much faster than that of some hydrophobic retinoids. Third, introduction of an $N$-methyl group into the amide group of 3 and 4 (yielding 5 and 6 , respectively), caused a dramatic disappearance of the retinoidal activities due to the conformational change of the amide group. ${ }^{19)}$ Thus, the secondary aromatic amides 3 and 4 have a trans-amide bond and their whole structures are elongated, while the tertiary aromatic amides $\mathbf{5}$ and $\mathbf{6}$ have a cis-amide bond and the two benzene rings are folded face to face. ${ }^{20}$ ) Structurally, the position of the amide group of $\mathbf{3}$ and $\mathbf{4}$ corresponds to the 9-ene part of retinoic acid (1). These results suggested that introduction of a trans- or cis-amide bond into the 9,10-position of retinoic acid (1) affording the dienamides $7 \mathbf{a}-\mathbf{1 0 a}$ might yield analogs of $\mathbf{1}$ or its 9-cis isomer (2) with properties like those of retinoidal aromatic amides. Here we describe the syntheses, conformational analyses and biological activities of several dienamides and related aromatic amides.

Synthesis Replacement of the central olefinic bond of 
the pentaene system of retinoic acid (1) with an amide group would afford compounds $7 \mathbf{a}-\mathbf{1 0 a}$, which have dienyl moieties on both sides of the amide bond. As dienamides are generally useful precursors for inter- and intramolecular Diels-Alder reactions ${ }^{21,22)}$ which have been applied to the synthesis of natural products, ${ }^{23)}$ several<smiles></smiles>

3 (Am80)<smiles>CN(C(=O)c1ccc(C(=O)O)cc1)c1ccc2c(c1)CC(C)(C)C2</smiles><smiles>CC1=C(/C=C/NC(=O)/C=C/C=C/C(=O)O)CCCC1(C)C</smiles>

$7 a$<smiles>CC1=C(/C=C/N(C)C(=O)/C=C/C=C/C(=O)O)CCCC1(C)C</smiles>

$9 a$<smiles></smiles>

4 (Am580)<smiles>CN(C(=O)c1ccc2c(c1)CC(C)(C)C2)c1ccc(C(=O)O)cc1</smiles><smiles>CC1=C(/C=C/C(=O)N/C=C/C=C/C(=O)O)C(C)(C)CCC1</smiles>

$8 \mathbf{a}$<smiles>CC1=C(/C=C/C(=O)N(C)C/C=C/C=C(\O)C(=O)O)CCCC1(C)C</smiles>

$10 a$ synthetic methods for dienamides or enamides have been developed, ${ }^{24)}$ such as acylation of conjugated imines, ${ }^{25}$ ) elimination of $\alpha$ - or $\beta$-carbamidosulfones, ${ }^{26,27)}$ and $\alpha$ alkenylation by modified Peterson ${ }^{28)}$ or Horner-Wittig reactions. ${ }^{29)}$ However, these methods are applicable only to a limited range of dienamides, such as tertiary amides or aromatic ring-conjugated systems. Furthermore, conformational properties of such dienamides have rarely been investigated.

Our synthetic strategy for the secondary dienamides $7 \mathbf{a}$ and 8a was the conversion of a conjugated dienoic acid into $\mathrm{N}$-acylamino-1,3-dienes by means of modified Curtius rearrangements, ${ }^{30)}$ followed by acylation. The synthetic route to $7 \mathbf{a}$ is shown in Chart 1 . $\beta$-Ionone (11) was oxidized by basic bromine to give 3-(2,6,6-trimethyl-1-cyclohexen-1-yl)-2-propenoic acid (12), which was converted to the acid azide 14. Then 14 was heated in the presence of methanol at reflux to give a carbamate $\mathbf{1 5}$ as a stable crystalline solid in quantitative yield. From the ${ }^{1} \mathrm{H}-\mathrm{NMR}$ spectrum, 15 has a trans-olefinic bond $(J=15 \mathrm{~Hz})$ like the starting acid azide 14. Condensation of the anion generated from 15 with muconic acid monomethyl ester chloride (16) gave the $\mathrm{N}$-acylated product 17 in $79 \%$ yield. The methoxycarbonyl group was removed by refluxing with one equivalent of lithium iodide in $N, N$-dimethylformamide (DMF) to give a secondary dienamide $7 \mathrm{~b}$ in $86 \%$ yield, and its terminal ester was hydrolyzed under a basic condition to afford 7a. Similarly, another secondary dienamide 8a was synthesized starting from the acid azide (19) of muconic acid monomethyl ester (18) and 13 as shown in Chart 2.

$\mathrm{N}$-Methylations of the secondary dienamides, $\mathbf{7 b}$ and 8b, with $\mathrm{NaH} / \mathrm{CH}_{3} \mathrm{I}$ in dry DMF gave the tertiary<smiles>CC(=O)/C=C/C1=C(C)CCCC1(C)C</smiles>

11<smiles>[Y]C(=O)/C=C/C1=C(C)CCC(C)C1(C)C</smiles>

$12 \mathrm{X}=\mathrm{OH}$ $13 X=\mathrm{Cl}$
$14 X=\mathrm{N}_{3}$

1) $\mathrm{Lil} \cdot 2 \mathrm{H}_{2} \mathrm{O} / \mathrm{DMF}$ 2) $\mathrm{NaOH} / \mathrm{CH}_{3} \mathrm{OH}$<smiles>C=C</smiles><smiles>COC(=O)N/C=C/C1=C(C)CCCC1(C)C</smiles>

15<smiles>CC1=C(/C=C/NC(=O)/C=C/C=C/C(=O)O)C(C)(C)CCC1</smiles>
$\begin{aligned} 7 b \mathrm{~b} & =\mathrm{CH}_{3} \\ 7 \mathrm{a} R & =\mathrm{H}\end{aligned}$

Chart 1

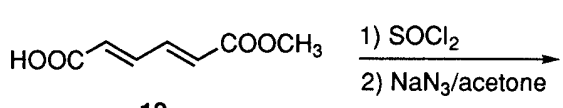

18<smiles>COC(=O)C=CC=CC(=O)OC</smiles>

$16 \mathrm{X}=\mathrm{Cl}$
$19 \mathrm{X}=\mathrm{N}_{3}$
$\stackrel{\Delta / \mathrm{CH}_{3} \mathrm{OH} / 0 \text {-xylene }}{\longrightarrow}$<smiles>COC(=O)C=CC=CNC(=O)OC</smiles>

20

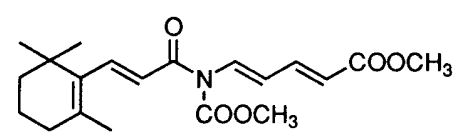

21<smiles>CC1=C(/C=C/C(=O)N/C=C/C=C/C(=O)O)C(C)(C)CCC1</smiles>

$8 b \mathrm{R}=\mathrm{CH}_{3}$

$8 a R=H$ 


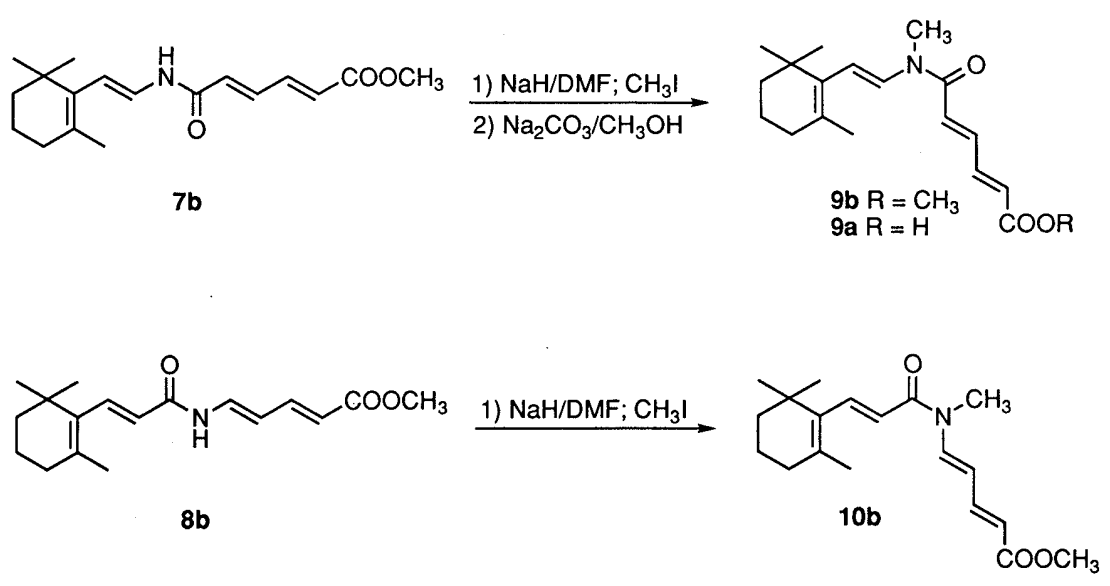

Chart 3

dienamides $\mathbf{9 b}$ and $\mathbf{1 0 b}$, respectively (Chart 3). Since the stability of secondary and tertiary dienamides under basic conditions is very different, ester hydrolysis of $\mathbf{9 b}$ was carefully performed with $\mathrm{Na}_{2} \mathrm{CO}_{3}$ in methanol to give $9 \mathbf{a}$. However, the reaction of $\mathbf{1 0 b}$ with various basic reagents such as lithium carbonate resulted in the cleavage of the amide bond. Treatment of $\mathbf{1 0 b}$ with lithium iodide caused cleavage of the enamine $\mathrm{C}-\mathrm{N}$ bond. The tert-butyl ester of $10 \mathbf{a}$ was prepared from $8 \mathbf{a}$ by esterification followed by $N$-methylation, but attempts to remove the tert-butyl group under various conditions (thermal, acidic, and other ester cleavage reagents) resulted in decomposition of the dienamide structure.

Previously, we reported the synthesis and the differentiation-inducing activities of two retinoidal dienoic anilides, 22a and 23a, which are structural hybrid compounds between retinoic acid (1) and Am80 (3) or Am580 (4). ${ }^{13,14)}$ These compounds also possess the amide group at the position corresponding to the 9-ene structure of 1. In order to clarify the relationship between the conformations of amide bonds and the biological activities, $N$-methyl analogs of 22a and 23a were synthesized. $\mathrm{N}$-Methylation of the secondary amides $\mathbf{2 2 \mathbf { b }}$ and $\mathbf{2 3 \mathbf { b }}$ followed by hydrolysis afforded the tertiary amides $\mathbf{2 4 a}$ and 25a, respectively. The dienamide 26a, an isomer of $23 \mathrm{a}$, was prepared by condensation of the carbamate 15 with terephthalic acid monomethyl ester chloride, followed by hydrolysis as described above. Although
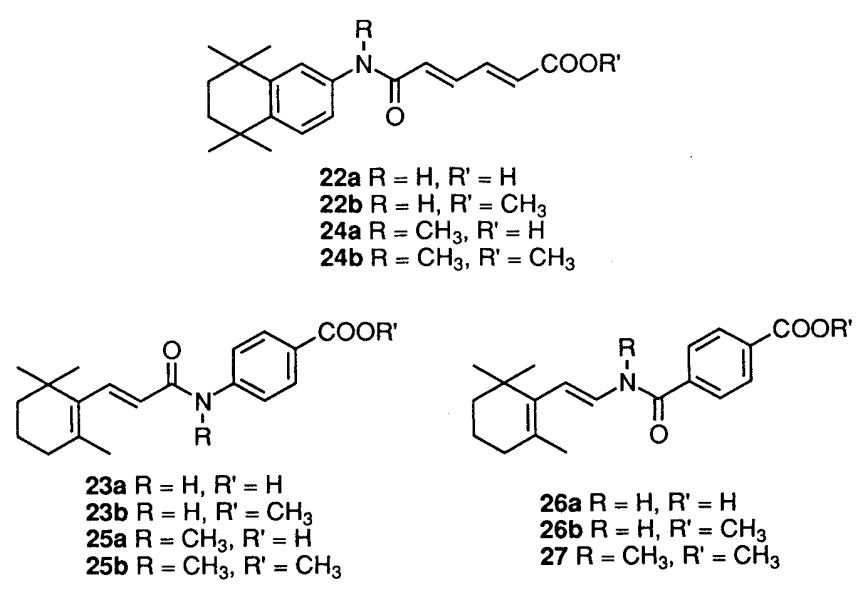

$N$-methylation of $\mathbf{2 6} \mathbf{b}$ afforded a tertiary dienamide $\mathbf{2 7}$, the terminal ester could not be removed under basic conditions without decomposition of the dienamide skeleton.

Conformational Studies NMR spectroscopic and Xray crystallographic studies have shown that the retinoidally active aromatic anilides, Am80 (3) and Am580 (4), have a trans-amide bond, and their whole structures are elongated. $N$-Methylation of these amides caused a dramatic change of the amide stereochemistry (cispreference in tertiary amides) and the disappearance of retinoidal activities. ${ }^{19,20)}$ Such preference of cis form is general among simple aromatic anilides. ${ }^{31)}$ Thus, $N$ methylbenzanilide has a cis-amide bond in the crystal, and exists predominantly in $c i s$-form $(99 \%)$ in $\mathrm{CDCl}_{3}{ }^{32}$ ) $N$-Acyl- $N$-methylanilines also exist in cis-amide forms irrespective of the acyl moiety. ${ }^{33)}$ In order to clarify the relationship between the amide stereochemistry and the retinoidal activities of the dienamides or dienoic anilides synthesized here, their conformations were studied by NMR spectroscopy at various temperatures. Since esterification of the terminal carboxyl group did not affect the conformation of the amide group in each case (i.e., there is little or no change in chemical shifts between the acid and the ester), NMR studies were performed on the methyl ester derivatives in $\mathrm{CDCl}_{3}$.

The amide 24b with the $N$-acyl- $N$-methylaniline skeleton shows the proton absorption of two aromatic protons ortho to the amide group shifted to higher field $(\Delta \delta$ $0.5 \mathrm{ppm}$ ) than those in $\mathbf{2 2} \mathbf{b}$, which is characteristic of cis-anilides. The $\alpha$-olefinic proton to the amide-carbonyl group of $\mathbf{2 4 b}$ also shifted to higher field than the corresponding proton in $\mathbf{2 2 b}$ due to the anisotropic effect of the aromatic ring. Nuclear Overhauser effect (NOE) enhancement from the $\alpha$-proton to the aromatic protons (2-3\% for both ortho-protons) supported the cis conformation for $\mathbf{2 4 b}$. Essentially a single isomer is present in solution because only one set of proton signals was observed for $24 b$ even at $-60^{\circ} \mathrm{C}$. On the other hand, the NMR spectrum of the secondary anilide $\mathbf{2 2 b}$ clearly shows the presence of a minor component $(\mathrm{ca} .1 \%)$ at $-60^{\circ} \mathrm{C}$. This suggests that $\mathbf{2 2 b}$ exists in equilibrium between trans- $(99 \%)$ and cis-amide forms $(1 \%)$ in $\mathrm{CDCl}_{3}$, since the NMR absorptions of the minor conformer are virtually 
superposable on those of 24b. Similar results were obtained in the case of another pair of $N$-acyldienoic anilides, 23b and 25b. Both compounds exhibited proton absorptions consistent with the presence of a single conformer even at $-60^{\circ} \mathrm{C}$. The chemical shift differences between $23 \mathrm{~b}$ and $\mathbf{2 5 b}$ correlate well with those between $\mathbf{2 2 b}$ and $\mathbf{2 4 b}$. Furthermore, NOE enhancement $(20 \%)$ was observed between the amide proton and olefinic $\alpha$-proton to the amide-carbonyl group in $\mathbf{2 2 b}$. Thus, 22b exists in trans form, and $24 \mathbf{b}$ exists in cis form in $\mathrm{CDCl}_{3}$.

The secondary dienamide $\mathbf{2 6} \mathbf{b}$ exhibited only one set of proton absorptions in $\mathrm{CDCl}_{3}$ even at $-60^{\circ} \mathrm{C}$, and $\mathrm{NOE}$ enhancement $(16 \%)$ between the amide proton and aromatic protons ortho to the amide carbonyl revealed that 26b exists in the trans conformation. On the other hand, the $\mathrm{N}$-methylated dienamide 27 exists in equilibrium between two conformers $\left(4.6: 1\right.$ at $\left.20^{\circ} \mathrm{C}\right)$ in $\mathrm{CDCl}_{3}$. The olefinic proton adjacent to the amide nitrogen of the major conformer was observed at higher field $(6.25 \mathrm{ppm})$ than that of the minor conformer $(7.37 \mathrm{ppm})$. Considering the anisotropic effect of the aromatic ring and the amide carbonyl group, the major conformer is in the cis-amide form, whereas the minor conformer is in the trans-amide form.

The conformational tendencies of the dienoyl dienamides $\mathbf{7 b}$ and $\mathbf{9 b}$ are similar to those of $\mathbf{2 6 b}$ and $\mathbf{2 7}$. The secondary dienamides $\mathbf{7 b}$ and $\mathbf{8 b}$ exist in trans-amide form in $\mathrm{CDCl}_{3}$, as deduced from NOE experiments. Large NOE enhancements were observed from the amide proton to $\mathrm{H}_{7}(16 \%)$ and $\mathrm{H}_{11}(22 \%)$ of $7 \mathbf{b}$ (Chart 4). NMR spectra of the tertiary dienamides $9 \mathrm{~b}$ and $10 \mathrm{~b}$ at $-40^{\circ} \mathrm{C}$ showed that both compounds exist in equilibrium between trans and cis conformers. The trans/cis ratio is $1: 2.7$ for $\mathbf{9 b}$, and $1: 1.7$ for $10 \mathrm{~b}$. Their chemical shift differences are less than those of the aromatic amide compounds, only the olefinic proton adjacent to the amide nitrogen (i.e., $\mathrm{H}_{8}$ for $9 \mathbf{b}$, and $\mathrm{H}_{11}$ for $10 \mathrm{~b}$ ) being clearly distinguishable between the two conformers, owing to the anisotropy of the amide carbonyl group. The proton absorption of $\mathrm{H}_{8}$ in the major conformer of $9 \mathbf{b}(6.57 \mathrm{ppm})$ was observed at higher field than that in the minor conformer $(7.29 \mathrm{ppm})$. There was also a chemical shift difference $(\Delta \delta 0.1 \mathrm{ppm})$ at $\mathrm{H}_{11}$ ( $\alpha$-proton to the amide carbonyl) between the conformers. Furthermore, NOE enhancement $(10 \%)$ was observed between $\mathrm{H}_{8}$ and $\mathrm{H}_{11}$ of $9 \mathrm{~b}$ at $-40^{\circ} \mathrm{C}$. Thus, the major and the minor conformers of $\mathbf{9 b}$ were assigned as the cis- and the trans-amide forms, respectively. Similarly, the major conformer of $\mathbf{1 0 b}$ was determined to be the cis-amide, in which the $\mathrm{H}_{11}$ proton was observed at higher field $(7.52 \mathrm{ppm})$ than that of the minor trans-conformer (7.99 ppm). Thus, $N$-methylation of secondary dienamides resulted in cis-preference, as observed in many $N$-methyl amides. In contrast to the predominancy of cis conformation in $N$-methylbenzanilide or $N$-methylacylanilides, the stabilities of the trans- and cis-conformers of these tertiary dienamides are comparable. Although the origin of cis-preference of tertiary $N$-methylamides is not well understood at present, it may be general that an $N$-phenyl group in $N$-methylamides tends to favor the trans position to the carbonyl oxygen much more than an $N$-vinyl group does.

Biological Activities Retinoidal activities of the amide derivatives were evaluated in terms of the ability to induce differentiation of human promyelocytic leukemia cell line HL-60 to mature granulocytes. ${ }^{34,35)}$ This activity of retinoids correlates well with other retinoidal activities. ${ }^{1,11)}$ The morphological changes were examined by microscopy after Wright-Giemsa staining, and the differentiation state was also determined by means of nitro blue tetrazolium

TABLE I. Differentiation-Inducing Activities of Aromatic and Polyene Amides

\begin{tabular}{ccc}
\hline Compd. & $\mathrm{EC}_{50}{ }^{a)}(\mathrm{M})$ & Rel. act. $^{b)}$ \\
\hline Retinoic acid (1) & $2.4 \times 10^{-9}$ & $100^{c)}$ \\
9-cis-Retinoic acid (2) & $2.2 \times 10^{-9}$ & \\
Am80 (3) & $7.9 \times 10^{-10}$ & $350^{c)}$ \\
Am580 (4) & $3.4 \times 10^{-10}$ & $720^{c)}$ \\
Am90 (5) & $>10^{-6}$ & $<10^{-2 c}$ \\
Am590(6) & $>10^{-6}$ & $<10^{-2}$ ) \\
$\mathbf{7 a}$ & $7.2 \times 10^{-7}$ & 0.43 \\
$\mathbf{8 a}$ & $4.3 \times 10^{-7}$ & 0.73 \\
$\mathbf{9 a}$ & Inactive & \\
$\mathbf{2 2 a}$ & $4.0 \times 10^{-8}$ & $4.4^{c)}$ \\
$\mathbf{2 3 a}$ & $3.3 \times 10^{-8}$ & $4.9^{c)}$ \\
$\mathbf{2 4 a}$ & Inactive & \\
$\mathbf{2 5 a}$ & Inactive & 14 \\
$\mathbf{2 6 a}$ & $2.3 \times 10^{-8}$ & \\
\hline
\end{tabular}

a) $\mathrm{EC}_{50}$ values of active compounds were calculated from NBT reduction assay data. b) The ratio of $\mathrm{EC}_{50}$ (retinoic acid) to $\mathrm{EC}_{50}$ (test compound), both values having been obtained in concurrent experiments. $c$ ) The values were reported previously (refs. 14 and 37 ).

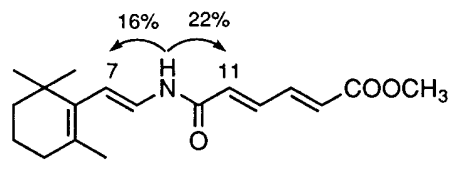

7b

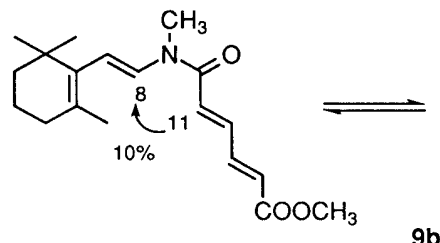<smiles>CC(=O)C=CC=CC(=O)N(C)C=CC1=C(C)CCCC1(C)C</smiles> 
(NBT) reduction assay as a functional marker of differentiation. ${ }^{36}$ ) These two indexes of differentiation correlated well each other. ${ }^{12,13)}$ The $\mathrm{EC}_{50}$ values evaluated from NBT reduction assay are listed in Table $\mathrm{I}$.

All the active compounds induced the differentiation of HL-60 cells into mature granulocytes, like retinoic acid (1). Two secondary dienamides $7 \mathbf{a}$ and $8 \mathbf{a}$ exhibited the differentiation-inducing activity at concentrations above $10^{-7} \mathrm{M}$. Replacement of the $N$-dienyl group of $7 \mathbf{a}$ and $\mathbf{8 a}$ with an aromatic ring, yielding $22 \mathbf{a}$ and $23 \mathbf{a}$, respectively, increased the activity $\left(\mathrm{EC}_{50}\right.$ s of $\left.3-4 \times 10^{-8} \mathrm{M}\right)$. Replacement of the $N$-acyl group with a benzoyl moiety also caused increased activity. Thus, the dienamide 26a is as active as its isomer 23a with a reversed amide bond. Structurally, Am80 and Am580 are derivatives of 7a and $8 \mathbf{a}$ with two aromatic rings instead of two diene moieties, respectively and are more active than the dienamides. Thus, the activity increased by one or two orders of magnitude when each dienyl component of the dienamides was replaced with an aromatic ring.

$N$-Methylation of the secondary amides always resulted in the disappearance of the activity. All the tertiary amide derivatives examined were completely inactive at concentrations below $10^{-6} \mathrm{M}$. This result is interesting for two reasons. First, some of the compounds, especially the tertiary dienamides, exist in equilibrium between transand cis-amide form. These compounds were expected to have differentiation-inducing activity to some extent, since the conformations of their trans forms sould be similar to those of the corresponding secondary amides and therefore to that of all-trans-retinoic acid at the receptor binding site. Second, 9-cis-retinoic acid (2) itself is potent differentiation-inducer of HL-60, ${ }^{37}$ ) and the structural features of the $N$-methyl amides appear to resemble those of 2 . In spite of the similarity, all the compounds having the $c i s$-amide bond were inactive. The cis-olefinic bond of $\mathbf{2}$ seems not to be replacable with a cis-amide bond without loss of retinoidal activity. Alternatively, $N$-methyl amides may bind with RXR, but not RAR, and only binding with RAR may be responsible for the HL-60 differentiation. 9-cis-Retinoic acid (2) can bind and activate RXRs as well as RARs. The tertiary dienamide 9a exhibited only weak binding potency (approximately $10^{3}$-fold weaker than that of 2 ) to a protein containing the ligand-binding domain of $\operatorname{RXR} \beta$, which was expressed using pMAL-c2 (NEB) and purified over amylose resin (data not shown). Recently, Dawson et al. reported the retinoidal activities of aromatic retinoids having a trans-, cis-olefinic bond, or a phenyl group (i.e. cis-restricted linking group) at the position corresponding to the 9-ene structure of retinoic acid. ${ }^{38)}$ In this case, the cis-isomers exhibited weak potencies to bind both specific receptors, RARs and RXR $\alpha$. The cis-linking group seems to be not effective in aromatic retinoids. Elementary investigations on the structural requirements of a RXR ligand seem to be necessary for further progress.

In conclusion, we synthesized several dienamides and related amide compounds, structurally based upon retinoic acid and retinobenzoic acids. The compounds with a trans-amide bond, which are regarded as analogs of all-trans-retinoic acid (1), showed differentiation-inducing activity on HL-60 cells. Ene-amide structures can replace the ene group of all-trans-retinoic acid. Although the amide group decreased the activity, compared with retinoic acid or retinobenzoic acids, these amide compounds should exhibit pharmacological properties different from those of retinoic acid and other hydrophobic retinoids, and may be useful for clinical application, since they are expected to have favorable pharmacokinetics in vivo. Investigations on the pharmacological behavior and other biological activities, including receptor-binding abilities of the active and inactive amides, are in progress.

\section{Experimental}

General Melting points were determined by using a Yanagimoto hot-stage melting point apparatus and are uncorrected. Elemental analyses were carried out in the Microanalytical Laboratory, Faculty of Pharmaceutical Sciences, University of Tokyo, and were within $\pm 0.3 \%$ of the theoretical values. ${ }^{1} \mathrm{H}$-NMR spectra were recorded on a JEOL JNM-GX400 $(400 \mathrm{MHz})$ spectrometer. Chemical shifts are expressed in $\mathrm{ppm}$ relative to tetramethylsilane. IR spectra were taken with a Shimadzu IR-408 infrared spectrometer and are expressed in $\mathrm{cm}^{-1}$. Preparations and physical properties of $\mathbf{2 2 a - 2 3 b}$ were reported previously. ${ }^{14)}$ Muconic acid was prepared from adipic acid in three steps according to the literature. ${ }^{39)}$

3-(2,6,6-Trimethyl-1-cyclohexen-1-yl)-2-propenoic Acid (12) Bromine $(6.95 \mathrm{~g}, 43.5 \mathrm{mmol})$ was added to $50 \mathrm{ml}$ of $2.5 \mathrm{~N} \mathrm{NaOH}$, and the mixture was stirred at $-5^{\circ} \mathrm{C}$ for $1 \mathrm{~h}$. A solution of $\beta$-ionone $(11,2.89 \mathrm{~g}, 15.0 \mathrm{mmol})$ in $25 \mathrm{ml}$ of tetrahydrofuran (THF) was added dropwise to the mixture below $-5^{\circ} \mathrm{C}$. The reaction mixture was vigorously stirred at $-5^{\circ} \mathrm{C}$ for $2 \mathrm{~h}$ and at room temperature for $4.5 \mathrm{~h}$, and then poured into $50 \mathrm{ml}$ of ice water. After acidification with $5 \%$ sulfuric acid, the mixture was extracted with ether. The organic layer was washed with brine and dried over $\mathrm{Na}_{2} \mathrm{SO}_{4}$. After evaporation, the crude product was recrystallized from $\mathrm{AcOEt} / n$-hexane to give $12(82 \%)$. 12: colorless prisms (AcOEt/ $n$-hexane), mp 108-109 ${ }^{\circ} \mathrm{C} .{ }^{1} \mathrm{H}$-NMR $\left(\mathrm{CDCl}_{3}\right) \delta: 1.08(6 \mathrm{H}, \mathrm{s}), 1.49(2 \mathrm{H}$, $\mathrm{m}), 1.62(2 \mathrm{H}, \mathrm{m}), 1.79(3 \mathrm{H}, \mathrm{s}), 2.10(2 \mathrm{H}, \mathrm{m}), 5.87(1 \mathrm{H}, \mathrm{d}, J=15 \mathrm{~Hz})$, $7.57(1 \mathrm{H}, \mathrm{d}, J=15 \mathrm{~Hz})$. Anal. Calcd for $\mathrm{C}_{12} \mathrm{H}_{18} \mathrm{O}_{2}: \mathrm{C}, 74.19 ; \mathrm{H}, 9.34$. Found: C, 74.02; H, 9.31.

Methyl (E)-2-(2,6,6-Trimethyl-1-cyclohexen-1-yl)ethenecarbamate (15) $\mathrm{SOCl}_{2}(20 \mathrm{ml})$ was added to a solution of $12(5.60 \mathrm{~g}, 28.8 \mathrm{mmol})$ in dry benzene $(150 \mathrm{ml})$, and the mixture was stirred for $6 \mathrm{~h}$ with protection from light. After removal of the solvent and excess $\mathrm{SOCl}_{2}$, the residue (crude 13) was dissolved in $100 \mathrm{ml}$ of acetone, and a solution of $\mathrm{NaN}_{3}$ $(2.50 \mathrm{~g}, 34.6 \mathrm{mmol})$ in $5 \mathrm{ml}$ of water and $100 \mathrm{ml}$ of acetone was added at $-10^{\circ} \mathrm{C}$ over $30 \mathrm{~min}$. The mixture was stirred for $4 \mathrm{~h}$ with protection from light, and then poured into saturated aqueous $\mathrm{NaHCO}_{3}$, and extracted with benzene. The organic layer was washed with water and brine, dried over $\mathrm{MgSO}_{4}$, and concentrated to $300 \mathrm{ml}$. Methanol (300 ml) was added to the crude solution of $\mathbf{1 4}$ in benzene, and the mixture was heated gradually. After refluxing for $3 \mathrm{~h}$, the mixture was evaporated and the residue was purified by recrystallization from $\mathrm{AcOEt} / n$-hexane to give $15(80 \%)$. 15: colorless prisms (AcOEt $/ n$-hexane), mp 118.5$119.5^{\circ} \mathrm{C} .{ }^{1} \mathrm{H}-\mathrm{NMR}\left(\mathrm{CDCl}_{3}\right) \delta: 1.00(6 \mathrm{H}, \mathrm{s}), 1.48(2 \mathrm{H}, \mathrm{m}), 1.62(2 \mathrm{H}, \mathrm{m})$, $1.78(3 \mathrm{H}, \mathrm{s}), 2.10(2 \mathrm{H}, \mathrm{m}), 3.78(3 \mathrm{H}, \mathrm{s}), 5.87(1 \mathrm{H}, \mathrm{d}, J=15 \mathrm{~Hz}), 7.30$ $(1 \mathrm{H}, \mathrm{s}), 7.57(1 \mathrm{H}, \mathrm{d}, J=15 \mathrm{~Hz})$. IR $(\mathrm{KBr}): 1620 \mathrm{~cm}^{-1}$. Anal. Calcd for $\mathrm{C}_{13} \mathrm{H}_{21} \mathrm{NO}_{2}: \mathrm{C}, 69.91 ; \mathrm{H}, 9.48 ; \mathrm{N}, 6.27$. Found: $\mathrm{C}, 69.89 ; \mathrm{H}, 9.59 ; \mathrm{N}$, 6.31 .

Methyl $N$-Methoxycarbonyl- $N$-[2-(2,6,6-trimethyl-1-cyclohexen-1-yl)ethenyl]muconamate (17) $\mathrm{NaH}(60 \%, 480 \mathrm{mg}, 12.0 \mathrm{mmol})$ was added to a solution of $15(2.23 \mathrm{~g}, 10.0 \mathrm{mmol})$ in $100 \mathrm{ml}$ of dry DMF at $0{ }^{\circ} \mathrm{C}$. Then, a solution of $2.0 \mathrm{~g}(12.0 \mathrm{mmol})$ of muconic acid monomethyl ester chloride (16, see the section on 20) in $50 \mathrm{ml}$ of benzene was added to the yellow reaction mixture at $0^{\circ} \mathrm{C}$, and the whole was stirred for $1 \mathrm{~h}$. After removal of the solvent, the residue was diluted with AcOEt and saturated aqueous $\mathrm{NaHCO}_{3}$. The organic layer was dried over $\mathrm{Na}_{2} \mathrm{SO}_{4}$ and evaporated. The residue was chromatographed on silica gel to give $17(79 \%)$ and the demethoxycarbonylated compound $7 \mathbf{b}(15 \%)$. 17: pale yellow prisms (AcOEt $/ n$-hexane), mp $113-114^{\circ} \mathrm{C} .{ }^{1} \mathrm{H}-\mathrm{NMR}\left(\mathrm{CDCl}_{3}\right)$ $\delta: 1.05(6 \mathrm{H}, \mathrm{s}), 1.48(2 \mathrm{H}, \mathrm{m}), 1.62(2 \mathrm{H}, \mathrm{m}), 1.78(3 \mathrm{H}, \mathrm{s}), 2.05(2 \mathrm{H}, \mathrm{m})$, $3.79(3 \mathrm{H}, \mathrm{s}), 3.86(3 \mathrm{H}, \mathrm{s}), 6.02(2 \mathrm{H}, \mathrm{s}), 6.20(1 \mathrm{H}, \mathrm{m}), 7.10(1 \mathrm{H}, \mathrm{m}), 7.39$ $(2 \mathrm{H}, \mathrm{m})$. IR (KBr): $1720,1600 \mathrm{~cm}^{-1}$. Anal. Calcd for $\mathrm{C}_{20} \mathrm{H}_{27} \mathrm{NO}_{5}$ : C, 
$66.45 ; \mathrm{H}, 7.53 ; \mathrm{N}, 3.88$. Found: C, 66.45; H, 7.65; N, 4.16.

Methyl $N$-[2-(2,6,6-Trimethyl-1-cyclohexen-1-yl)ethenyl]muconamate (7b) $\mathrm{LiI} \cdot 2 \mathrm{H}_{2} \mathrm{O}(1.13 \mathrm{~g}, 5.9 \mathrm{mmol})$ was added to a solution of $17(2.10 \mathrm{~g}$, $5.8 \mathrm{mmol}$ ) in $50 \mathrm{ml}$ of dry DMF, and the mixture was refluxed for $8 \mathrm{~h}$. After removal of the solvent, the residue was diluted with AcOEt and saturated aqueous $\mathrm{NaHCO}_{3}$. The organic layer was washed with brine and dried over $\mathrm{Na}_{2} \mathrm{SO}_{4}$. After evaporation, the residue was chromatographed on silica gel to give $7 \mathbf{b}(86 \%)$. $7 \mathbf{b}$ : pale yellow prisms (AcOEt/ $n$-hexane), mp $168^{\circ} \mathrm{C} .{ }^{1} \mathrm{H}$-NMR $\left(\mathrm{CDCl}_{3}\right) \delta: 0.98(6 \mathrm{H}, \mathrm{s}), 1.46(2 \mathrm{H}, \mathrm{m})$, $1.59(2 \mathrm{H}, \mathrm{m}), 1.71(3 \mathrm{H}, \mathrm{s}), 2.00(2 \mathrm{H}, \mathrm{m}), 3.80(3 \mathrm{H}, \mathrm{s}), 5.72(1 \mathrm{H}, \mathrm{d}$, $J=15 \mathrm{~Hz}), 6.20(2 \mathrm{H}, \mathrm{m}), 6.81(1 \mathrm{H}, \mathrm{dd}, J=15,12 \mathrm{~Hz}), 7.37(2 \mathrm{H}, \mathrm{m})$, $7.52(\mathrm{lH}, \mathrm{d}, J=12 \mathrm{~Hz})$. IR $(\mathrm{KBr}): 1715,1610 \mathrm{~cm}^{-1}$. Anal. Calcd for $\mathrm{C}_{18} \mathrm{H}_{25} \mathrm{NO}_{3}$ : C, 71.26; H, 8.31; N, 4.62. Found: C, 71.00; H, 8.41; N, 4.78.

$\mathrm{N}$-[2-(2,6,6-Trimethyl-1-cyclohexen-1-yl)ethenyl]muconamic Acid (7a) A solution of $2 \mathrm{~N} \mathrm{NaOH}(4 \mathrm{ml})$ was added to solution of 18 (100 mg, $0.33 \mathrm{mmol}$ ) in $20 \mathrm{ml}$ of methanol. After $12 \mathrm{~h}$, the mixture was poured into $1 \mathrm{~N}$ hydrochloric acid, and extracted with AcOEt. The organic layer was dried over $\mathrm{Na}_{2} \mathrm{SO}_{4}$ and evaporated. The residue was purified by recrystallization from AcOEt $/ n$-hexane to give 7a $(72 \%)$. 7a: pale yellow prisms (AcOEt $/ n$-hexane), mp 226-228 ${ }^{\circ} \mathrm{C} .{ }^{1} \mathrm{H}-\mathrm{NMR}\left(\mathrm{CD}_{3} \mathrm{OD}\right) \delta: 1.01$ $(6 \mathrm{H}, \mathrm{s}), 1.49(2 \mathrm{H}, \mathrm{m}), 1.61(2 \mathrm{H}, \mathrm{m}), 1.72(3 \mathrm{H}, \mathrm{s}), 2.03(2 \mathrm{H}, \mathrm{s}), 5.82(1 \mathrm{H}$, $\mathrm{d}, J=15 \mathrm{~Hz}), 6.21(1 \mathrm{H}, \mathrm{d}, J=15 \mathrm{~Hz}), 6.37(1 \mathrm{H}, \mathrm{d}, J=15 \mathrm{~Hz}), 6.72(1 \mathrm{H}$, $\mathrm{d}, J=15 \mathrm{~Hz}), 7.31(2 \mathrm{H}, \mathrm{m})$. IR $(\mathrm{KBr}): 1725,1630 \mathrm{~cm}^{-1}$. Anal. Calcd for $\mathrm{C}_{17} \mathrm{H}_{23} \mathrm{NO}_{3}$ : C, 70.55; H, 8.02; N, 4.84. Found: C, 70.26; H, 8.10; N, 4.82 .

Methyl 5-(Methoxycarbonylamino)-2,4-pentadienoate (20) Sulfuric acid $(25 \mathrm{ml})$ was added to a solution of muconic acid $(10.0 \mathrm{~g}, 70.3 \mathrm{mmol})$ in $500 \mathrm{ml}$ of methanol, and the mixture was refluxed for $3 \mathrm{~h}$. After evaporation, the residue was diluted with AcOEt and water. The organic layer was washed with water and dried over $\mathrm{Na}_{2} \mathrm{SO}_{4}$. After evaporation, the crude product was recrystallized from methanol to give dimethyl muconate $\left(83 \%, \mathrm{mp} 158-158.5^{\circ} \mathrm{C}\right)$. A solution of $\mathrm{KOH}(1.94 \mathrm{~g})$ in $20 \mathrm{ml}$ of methanol and $5 \mathrm{ml}$ of water was added dropwise to a solution of dimethyl muconate $(5.0 \mathrm{~g}, 29.4 \mathrm{mmol})$ in $300 \mathrm{ml}$ of methanol at $60^{\circ} \mathrm{C}$ over $2 \mathrm{~h}$, and the mixture was stirred for $2 \mathrm{~h}$. After evaporation, the residue was diluted with AcOEt and saturated aqueous $\mathrm{NaHCO}_{3}$. The aqueous layer was acidified with $2 \mathrm{~N} \mathrm{HCl}$ and extracted with AcOEt. The organic layer was dried over $\mathrm{Na}_{2} \mathrm{SO}_{4}$ and evaporated. The crude product was recrystallized from benzene to give $18(69 \%)$. 18: colorless plates (benzene), mp 163-164 ${ }^{\circ} \mathrm{C} .{ }^{1} \mathrm{H}-\mathrm{NMR}\left(\mathrm{CDCl}_{3}\right) \delta: 3.78(3 \mathrm{H}, \mathrm{s})$, $6.23(2 \mathrm{H}, \mathrm{m}), 7.37(2 \mathrm{H}, \mathrm{m})$. IR $(\mathrm{KBr}): 1700,1640,1610 \mathrm{~cm}^{-1}$. Anal. Calcd for $\mathrm{C}_{7} \mathrm{H}_{8} \mathrm{O}_{4}: \mathrm{C}, 53.85 ; \mathrm{H}, 5.16$. Found: C, 53.66; H, 5.12. A solution of $18(4.0 \mathrm{~g}, 25.6 \mathrm{mmol})$ in $20 \mathrm{ml}$ of $\mathrm{SOCl}_{2}$ was heated at $60^{\circ} \mathrm{C}$ with protection from light for $3 \mathrm{~h}$. Removal of excess $\mathrm{SOCl}_{2}$ gave a residue (crude 16), which was dissolved in $50 \mathrm{ml}$ of dry acetone, and a suspension of $1.99 \mathrm{~g}(27.6 \mathrm{mmol})$ of $\mathrm{NaN}_{3}(90 \%)$ in $100 \mathrm{ml}$ of dry acetone was added dropwise to the solution at $-10^{\circ} \mathrm{C}$. After $4 \mathrm{~h}$, the mixture was poured into $400 \mathrm{ml}$ of $o$-xylene. The organic layer was washed with saturated aqueous $\mathrm{NaHCO}_{3}$, water and brine, and dried over $\mathrm{MgSO}_{4}$. After filtration under vacuum, the solution was concentrated to $200 \mathrm{ml}$. Dry methanol $(400 \mathrm{ml})$ was added to a solution of the crude 19 in $o$ xylene, and the mixture was heated gradually, then refluxed for $3 \mathrm{~h}$. After removal of the solvent, the residue was recrystallized from $\mathrm{AcOEt} / n$ hexane to give $20(72 \%)$. 20: pale yellow prisms (AcOEt $/ n$-hexane), mp $176-178^{\circ} \mathrm{C} .{ }^{1} \mathrm{H}-\mathrm{NMR}\left(\mathrm{CDCl}_{3}\right) \delta: 3.73(3 \mathrm{H}, \mathrm{s}), 3.79(3 \mathrm{H}, \mathrm{s}), 5.78(1 \mathrm{H}$, $\mathrm{d}, J=15 \mathrm{~Hz}), 5.80(1 \mathrm{H}$, br t,$J=11 \mathrm{~Hz}), 6.84(1 \mathrm{H}$, br d, $J=11 \mathrm{~Hz}), 7.09$ $(1 \mathrm{H}$, br t, $J=11 \mathrm{~Hz}), 7.29(1 \mathrm{H}, \mathrm{dd}, J=11,15 \mathrm{~Hz})$. IR $(\mathrm{KBr}): 1720$, $1620 \mathrm{~cm}^{-1}$. Anal. Calcd for $\mathrm{C}_{8} \mathrm{H}_{11} \mathrm{NO}_{4}: \mathrm{C}, 51.87 ; \mathrm{H}, 5.99 ; \mathrm{N}, 7.56$. Found: C, 51.69; H, 5.89; N, 7.49.

Methyl 5-[N-(Methoxycarbonyl)- $N$-[3-(2,6,6-trimethyl-1-cyclohexen1-yl)-2-propenoyl] amino]-2,4-pentadienoate (21) $\mathrm{NaH}(60 \%, 480 \mathrm{mg}$, $12.0 \mathrm{mmol}$ ) was added to a solution of $20(1.85 \mathrm{~g}, 10.0 \mathrm{mmol})$ in $50 \mathrm{ml}$ of dry DMF at $0^{\circ} \mathrm{C}$. Then, a solution of $2.0 \mathrm{~g}(12.0 \mathrm{mmol})$ of 13 (see above) in $50 \mathrm{ml}$ of benzene was added to the yellow reaction mixture at $0^{\circ} \mathrm{C}$, and the whole was stirred for $1 \mathrm{~h}$. After removal of the solvent, the residue was diluted with AcOEt and saturated aqueous $\mathrm{NaHCO}_{3}$. The organic layer was dried over $\mathrm{Na}_{2} \mathrm{SO}_{4}$ and evaporated. The residue was chromatographed on silica gel to give $21(61 \%)$ and the demethoxycarbonylated compound $\mathbf{8 b}(4 \%)$. 21: colorless prisms (AcOEt $/ n$ hexane), mp $61-63.5^{\circ} \mathrm{C} .{ }^{1} \mathrm{H}-\mathrm{NMR}\left(\mathrm{CDCl}_{3}\right) \delta: 1.07(6 \mathrm{H}, \mathrm{s}), 1.48(2 \mathrm{H}$, $\mathrm{m}), 1.62(2 \mathrm{H}, \mathrm{m}), 1.82(3 \mathrm{H}, \mathrm{s}), 2.10(2 \mathrm{H}, \mathrm{m}), 3.74(3 \mathrm{H}, \mathrm{s}), 3.89(3 \mathrm{H}, \mathrm{s})$, $5.86(1 \mathrm{H}, \mathrm{d}, J=15 \mathrm{~Hz}), 6.29(1 \mathrm{H}, \mathrm{d}, J=14 \mathrm{~Hz}), 6.37(1 \mathrm{H}, \mathrm{dd}, J=11$, $14 \mathrm{~Hz}), 7.11(1 \mathrm{H}, \mathrm{d}, J=14 \mathrm{~Hz}), 7.31(1 \mathrm{H}, \mathrm{dd}, J=11,14 \mathrm{~Hz}), 7.59(1 \mathrm{H}$, $\mathrm{d}, J=16 \mathrm{~Hz})$. IR (KBr): $1720,1605 \mathrm{~cm}^{-1}$. Anal. Calcd for $\mathrm{C}_{20} \mathrm{H}_{27} \mathrm{NO}_{5}$ :
C, 66.45; H, 7.53; N, 3.88. Found: C, 66.79; H, 7.61; N, 4.11

Methyl 5-[[3-(2,6,6-Trimethyl-1-cyclohexen-1-yl)-2-propenoyl]amino]2,4-pentadienoate (8b) $\mathrm{LiI} \cdot 2 \mathrm{H}_{2} \mathrm{O}(0.94 \mathrm{~g}, 5.53 \mathrm{mmol})$ was added to a solution of $21(2.0 \mathrm{~g}, 5.53 \mathrm{mmol})$ in $70 \mathrm{ml}$ of dry DMF, and the mixture was refluxed for $8 \mathrm{~h}$. After removal of the solvent, the residue was diluted with AcOEt and saturated aqueous $\mathrm{NaHCO}_{3}$. The organic layer was washed with brine and dried over $\mathrm{Na}_{2} \mathrm{SO}_{4}$. After evaporation, the residue was chromatographed on silica gel to give $\mathbf{8 b}$ $(67 \%)$. 8b: pale yellow needles (AcOEt $/ n$-hexane), mp $128-128.5^{\circ} \mathrm{C}$. ${ }^{1} \mathrm{H}-\mathrm{NMR}\left(\mathrm{CDCl}_{3}\right) \delta: 1.05(6 \mathrm{H}, \mathrm{s}), 1.46(2 \mathrm{H}, \mathrm{m}), 1.59(2 \mathrm{H}, \mathrm{m}), 1.75(3 \mathrm{H}$, d), $2.08(2 \mathrm{H}, \mathrm{m}), 3.74(3 \mathrm{H}, \mathrm{s}), 5.75(1 \mathrm{H}, \mathrm{d}, J=15 \mathrm{~Hz}), 5.85(1 \mathrm{H}, \mathrm{d}$, $J=15 \mathrm{~Hz}), 5.93(1 \mathrm{H}, \mathrm{dd}, J=11,15 \mathrm{~Hz}), 7.34(1 \mathrm{H}, \mathrm{dd}, J=11,15 \mathrm{~Hz}), 7.48$ $(1 \mathrm{H}, \mathrm{t}, J=11 \mathrm{~Hz}), 7.52(1 \mathrm{H}, \mathrm{d}, J=15 \mathrm{~Hz}), 7.81(1 \mathrm{H}$, brd, $J=11 \mathrm{~Hz}) . \mathrm{IR}$ (KBr): $1715,1610 \mathrm{~cm}^{-1}$. Anal. Calcd for $\mathrm{C}_{18} \mathrm{H}_{25} \mathrm{NO}_{3}$ : C, 71.26; $\mathrm{H}, 8.31$; $\mathrm{N}, 4.62$. Found: C, 71.02; H, 8.23; N, 4.72.

5-[[3-(2,6,6-Trimethyl-1-cyclohexen-1-yl)-2-propenoyl]amino]-2,4pentadienoic Acid (8a) A solution of $2 \mathrm{~N} \mathrm{NaOH}(4 \mathrm{ml})$ was added to a solution of $8 \mathrm{~b}(107 \mathrm{mg}, 0.35 \mathrm{mmol})$ in $10 \mathrm{ml}$ of methanol, and the mixture was stirred overnight, poured into $30 \mathrm{ml}$ of $1 \mathrm{~N}$ hydrochloric acid, and extracted with AcOEt. The organic layer was dried over $\mathrm{Na}_{2} \mathrm{SO}_{4}$, and evaporated. The residue was recrystallized from AcOEt $/ n$-hexane to give 8a $(67 \%)$. 8a: pale yellow prisms (AcOEt $/ n$-hexane), mp $221.5-223^{\circ} \mathrm{C}$ ${ }^{1} \mathrm{H}-\mathrm{NMR}\left(\mathrm{CD}_{3} \mathrm{OD}\right) \delta: 1.10(6 \mathrm{H}, \mathrm{s}), 1.52(2 \mathrm{H}, \mathrm{m}), 1.66(2 \mathrm{H}, \mathrm{m}), 1.81$ $(3 \mathrm{H}, \mathrm{s}), 2.13(2 \mathrm{H}, \mathrm{m}), 5.76(1 \mathrm{H}, \mathrm{d}, J=15 \mathrm{~Hz}), 6.02(1 \mathrm{H}, \mathrm{d}, J=15 \mathrm{~Hz})$, $6.21(1 \mathrm{H}, \mathrm{dd}, J=11,15 \mathrm{~Hz}), 7.32(1 \mathrm{H}, \mathrm{dd}, J=11,15 \mathrm{~Hz}), 7.42(1 \mathrm{H}, \mathrm{d}$, $J=11 \mathrm{~Hz}), 7.48(1 \mathrm{H}, \mathrm{d}, J=15 \mathrm{~Hz})$. IR $(\mathrm{KBr}): 1720 \mathrm{~cm}^{-1}$. Anal. Calcd for $\mathrm{C}_{17} \mathrm{H}_{23} \mathrm{NO}_{3}: \mathrm{C}, 70.55 ; \mathrm{H}, 8.02 ; \mathrm{N}, 4.84$. Found: C, 70.31; H, 8.24; N, 5.06 .

Methyl $N$-Methyl- $N$-[2-(2,6,6-trimethyl-1-cyclohexen-1-yl)ethenyl]muconamate (9b) $\mathrm{NaH}(60 \%, 45 \mathrm{mg}, 1.10 \mathrm{mmol})$ was added to a solution of $7 \mathbf{b}(303 \mathrm{mg}, 1.0 \mathrm{mmol})$ in $20 \mathrm{ml}$ of dry DMF at $0^{\circ} \mathrm{C}$. After $5 \mathrm{~min}$, $2 \mathrm{ml}$ of methyl iodide was added to the red reaction mixture. The whole was stirred at $0^{\circ} \mathrm{C}$ for $1 \mathrm{~h}$, and then the solvent was removed under vacuum. The residue was poured into water, and extracted with AcOEt. The organic layer was dried over $\mathrm{Na}_{2} \mathrm{SO}_{4}$ and evaporated. The residue was chromatographed on silica gel to give $9 \mathrm{~b}(91 \%)$. 9b: pale yellow needles (AcOEt $/ n$-hexane), mp $105-106^{\circ} \mathrm{C} .{ }^{1} \mathrm{H}-\mathrm{NMR}\left(\mathrm{CDCl}_{3},-40^{\circ} \mathrm{C}\right)$ $\delta: 0.97(6 \mathrm{H}, \mathrm{s}), 1.42(2 \mathrm{H}, \mathrm{m}), 1.58(2 \mathrm{H}, \mathrm{m}), 1.70(3 \mathrm{H}, \mathrm{s}), 1.98(2 \mathrm{H}, \mathrm{m}), 3.24$ $(2.25 \mathrm{H}, \mathrm{s}), 3.28(0.75 \mathrm{H}, \mathrm{s}), 3.77(2.25 \mathrm{H}, \mathrm{s}), 3.78(0.75 \mathrm{H}, \mathrm{s}), 5.53(1 \mathrm{H}, \mathrm{d}$, $J=15 \mathrm{~Hz}), 6.20(1 \mathrm{H}, \mathrm{m}), 6.57(0.75 \mathrm{H}, \mathrm{d}, J=15 \mathrm{~Hz}), 6.73(0.75 \mathrm{H}, \mathrm{d}$, $J=15 \mathrm{~Hz}), 6.82(0.25 \mathrm{H}, \mathrm{m}), 7.46-7.25(2.25 \mathrm{H}, \mathrm{m}) . \mathrm{IR}(\mathrm{KBr}): 1720$, $1600 \mathrm{~cm}^{-1}$. Anal. Calcd for $\mathrm{C}_{19} \mathrm{H}_{27} \mathrm{NO}_{3}: \mathrm{C}, 71.89 ; \mathrm{H}, 8.58 ; \mathrm{N}, 4.41$. Found: C, 72.04; H, 8.71; N, 4.50.

$N$-Methyl- $N$-[2-(2,6,6-trimethyl-1-cyclohexen-1-yl)ethenyl]muconamic Acid (9a) A solution of $2 \mathrm{~N}$ aqueous $\mathrm{Na}_{2} \mathrm{CO}_{3}(4 \mathrm{ml})$ was added to a solution of $9 \mathrm{~b}(57 \mathrm{mg}, 0.18 \mathrm{mmol})$ in $10 \mathrm{ml}$ of methanol, and the mixture was stirred for $8 \mathrm{~d}$, poured into $1 \mathrm{~N}$ hydrochloric acid, and extracted with AcOEt. The organic layer was dried over $\mathrm{Na}_{2} \mathrm{SO}_{4}$ and evaporated. The residue was chromatographed on silica gel to give $9 \mathbf{a}(39 \%)$. 9a: pale yellow prisms (aqueous methanol), $\mathrm{mp} 71.5-73^{\circ} \mathrm{C} .{ }^{1} \mathrm{H}-\mathrm{NMR}\left(\mathrm{CD}_{3} \mathrm{OD}\right)$ $\delta: 1.05(6 \mathrm{H}, \mathrm{s}), 1.51(2 \mathrm{H}, \mathrm{m}), 1.66(2 \mathrm{H}, \mathrm{m}), 1.71(3 \mathrm{H}, \mathrm{d}), 2.05(2 \mathrm{H}, \mathrm{m})$, $3.25(1.8 \mathrm{H}, \mathrm{s}), 3.30(1.2 \mathrm{H}, \mathrm{s}), 5.71(1 \mathrm{H}, \mathrm{d}, J=15 \mathrm{~Hz}), 6.21(1 \mathrm{H}, \mathrm{m}), 6.72$ $(0.6 \mathrm{H}, \mathrm{d}, J=15 \mathrm{~Hz}), 6.91(0.6 \mathrm{H}, \mathrm{d}, J=15 \mathrm{~Hz}), 7.05(0.4 \mathrm{H}, \mathrm{d}, J=15 \mathrm{~Hz})$, $7.28-7.48(2.4 \mathrm{H}, \mathrm{m})$. IR $(\mathrm{KBr}): 1720,1605 \mathrm{~cm}^{-1}$. Anal. Calcd for $\mathrm{C}_{18} \mathrm{H}_{25} \mathrm{NO}_{3} \cdot 1 / 4 \mathrm{H}_{2} \mathrm{O}: \mathrm{C}, 71.26 ; \mathrm{H}, 8.31 ; \mathrm{N}, 4.62$. Found: C, 70.20; H, $8.29 ; \mathrm{N}, 4.46$.

Methyl 5-[N-Methyl- $N$-[3-(2,6,6-trimethyl-cyclohexen-1-yl)-2-propenoyl]amino]-2,4-pentadienoate (10b) $\mathrm{NaH}(60 \%, 83 \mathrm{mg}, 2.10 \mathrm{mmol})$ was added to a solution of $\mathbf{8 b}(560 \mathrm{mg}, 1.85 \mathrm{mmol})$ in $50 \mathrm{ml}$ of dry DMF at $0^{\circ} \mathrm{C}$. After $10 \mathrm{~min}, 2 \mathrm{ml}$ of methyl iodide was added and the mixture was stirred at room temperature for $2 \mathrm{~h}$. The solvent and excess methyl iodide was removed under vacuum, and AcOEt and water were added to the residue. The organic layer was dried over $\mathrm{Na}_{2} \mathrm{SO}_{4}$ and evaporated. The residue was chromatographed on silica gel to give $10 b(85 \%) .10 b$ : pale yellow oil. ${ }^{1} \mathrm{H}-\mathrm{NMR}\left(\mathrm{CDCl}_{3},-40^{\circ} \mathrm{C}\right) \delta: 1.03(6 \mathrm{H}, \mathrm{s}), 1.44(2 \mathrm{H}, \mathrm{m})$, $1.59(2 \mathrm{H}, \mathrm{m}), 1.76(3 \mathrm{H}, \mathrm{s}), 2.05(2 \mathrm{H}, \mathrm{m}), 3.25(2.1 \mathrm{H}, \mathrm{s}), 3.27(0.9 \mathrm{H}, \mathrm{s})$, $3.73(3 \mathrm{H}, \mathrm{s}), 5.90-5.75(2 \mathrm{H}, \mathrm{m}), 6.33(1 \mathrm{H}, \mathrm{d}, J=15 \mathrm{~Hz}), 7.30-7.50(2 \mathrm{H}$, $\mathrm{m}), 7.52(0.4 \mathrm{H}, \mathrm{d}, J=15 \mathrm{~Hz}), 7.99(0.6 \mathrm{H}, \mathrm{d}, J=15 \mathrm{~Hz})$. IR $(\mathrm{KBr})$ :
$1715 \mathrm{~cm}^{-1}$.

$N$-Methyl- $N$-(5,6,7,8-tetrahydro-5,5,8,8-tetramethyl-2-naphthalenyl)muconamic Acid (24a) $\mathrm{NaH}(60 \%, 80 \mathrm{mg}, 2.0 \mathrm{mmol})$ was added to a solution of $22 \mathbf{b}^{14)}(500 \mathrm{mg}, 1.46 \mathrm{mmol})$ in $20 \mathrm{ml}$ of dry DMF at $0^{\circ} \mathrm{C}$. After $5 \mathrm{~min}, 2 \mathrm{ml}$ of methyl iodide was added and the mixture was stirred at $0^{\circ} \mathrm{C}$ for $1 \mathrm{~h}$. The solvent and excess methyl iodide were removed under 
vacuum, and AcOEt and water were added to the residue. The organic layer was dried over $\mathrm{Na}_{2} \mathrm{SO}_{4}$, and evaporated. The residue was recrystallized from methanol to give $24 b(66 \%)$. $24 b$ : colorless prisms (methanol), mp $172-174{ }^{\circ} \mathrm{C} .{ }^{1} \mathrm{H}-\mathrm{NMR}\left(\mathrm{CDCl}_{3}\right) \delta: 1.25(6 \mathrm{H}, \mathrm{s}), 1.31$ $(6 \mathrm{H}, \mathrm{s}), 1.72(4 \mathrm{H}, \mathrm{s}), 6.13(1 \mathrm{H}, \mathrm{d}, J=15 \mathrm{~Hz}), 6.18(1 \mathrm{H}, \mathrm{d}, J=15 \mathrm{~Hz})$, $6.91(1 \mathrm{H}, \mathrm{dd}, J=2,8 \mathrm{~Hz}), 7.04(1 \mathrm{H}, \mathrm{d}, J=2 \mathrm{~Hz}), 7.16(1 \mathrm{H}, \mathrm{dd}, J=11$, $15 \mathrm{~Hz}), 7.31(1 \mathrm{H}, \mathrm{dd}, J=11,15 \mathrm{~Hz}), 7.33(1 \mathrm{H}, \mathrm{d}, J=8 \mathrm{~Hz})$. IR $(\mathrm{KBr})$ $1715,1680 \mathrm{~cm}^{-1}$. Anal. Calcd for $\mathrm{C}_{22} \mathrm{H}_{29} \mathrm{NO}_{3}: \mathrm{C}, 74.33 ; \mathrm{H}, 8.22 ; \mathrm{N}$, 3.94. Found: C, 74.21; H, 8.29; N, 4.06. A solution of $2 \mathrm{~N} \mathrm{NaOH}(5 \mathrm{ml})$ was added to a solution of $\mathbf{2 4 b}(100 \mathrm{mg}, 0.44 \mathrm{mmol})$ in $30 \mathrm{ml}$ of methanol, and the mixture was stirred overnight. After acidification with $2 \mathrm{~N}$ hydrochloric acid, the mixture was extracted with AcOEt. The organic layer was dried over $\mathrm{Na}_{2} \mathrm{SO}_{4}$, and evaporated. The residue was recrystallized from $\mathrm{CH}_{2} \mathrm{Cl}_{2} / n$-hexane to give $24 a(68 \%)$. 24a: pale yellow prisms $\left(\mathrm{CH}_{2} \mathrm{Cl}_{2} / n\right.$-hexane), mp $194-195^{\circ} \mathrm{C} .{ }^{1} \mathrm{H}-\mathrm{NMR}\left(\mathrm{CD}_{3} \mathrm{OD}\right) \delta: 1.27$ $(6 \mathrm{H}, \mathrm{s}), 1.31(6 \mathrm{H}, \mathrm{s}), 1.72(4 \mathrm{H}, \mathrm{s}), 6.16(1 \mathrm{H}, \mathrm{d}, J=15 \mathrm{~Hz}), 6.17(1 \mathrm{H}, \mathrm{d}$, $J=15 \mathrm{~Hz}), 7.02(1 \mathrm{H}, \mathrm{dd}, J=2.8 \mathrm{~Hz}), 7.10(1 \mathrm{H}, \mathrm{dd}, J=11,15 \mathrm{~Hz}), 7.17$ $(1 \mathrm{H}, \mathrm{d}, J=2 \mathrm{~Hz}), 7.24(1 \mathrm{H}, \mathrm{dd}, J=11,15 \mathrm{~Hz}), 7.44(1 \mathrm{H}, \mathrm{d}, J=8 \mathrm{~Hz}) . \mathrm{IR}$ (KBr): $1715,1690 \mathrm{~cm}^{-1}$. Anal. Calcd for $\mathrm{C}_{21} \mathrm{H}_{27} \mathrm{NO}_{3}: \mathrm{C}, 73.87 ; \mathrm{H}, 7.97$; N, 4.10. Found: C, 73.58; H, 7.95; N, 4.24.

4-[ $N$-Methyl-2-(2,6,6-trimethyl-1-cyclohexen-1-yl)ethylenecarboxamido]benzoic Acid (25a) $\mathrm{NaH}(60 \%, 14 \mathrm{mg}, 0.35 \mathrm{mmol})$ was added to a solution of $23 \mathbf{b}^{14)}(110 \mathrm{mg}, 0.34 \mathrm{mmol})$ in $10 \mathrm{ml}$ of dry DMF at $0^{\circ} \mathrm{C}$. After $30 \mathrm{~min}, 2 \mathrm{ml}$ of methyl iodide was added and the mixture was stirred at room temperature for $1 \mathrm{~h}$. The solvent and excess methyl iodide were removed under vacuum. AcOEt and water were added to the residue. The organic layer was dried over $\mathrm{Na}_{2} \mathrm{SO}_{4}$, and evaporated to give 25b $(97 \%)$. 25b: colorless oil. ${ }^{1} \mathrm{H}-\mathrm{NMR}\left(\mathrm{CDCl}_{3}\right) \delta: 0.95(6 \mathrm{H}, \mathrm{s})$, $1.41(2 \mathrm{H}, \mathrm{m}), 1.56(2 \mathrm{H}, \mathrm{m}), 1.60(3 \mathrm{H}, \mathrm{s}), 1.97(2 \mathrm{H}, \mathrm{m}), 3.41(3 \mathrm{H}, \mathrm{s}), 3.95$ $(3 \mathrm{H}, \mathrm{s}), 5.71(1 \mathrm{H}, \mathrm{d}, J=15.5 \mathrm{~Hz}), 7.28(2 \mathrm{H}, \mathrm{d}, J=8 \mathrm{~Hz}), 7.40(1 \mathrm{H}, \mathrm{d}$, $J=15.5 \mathrm{~Hz}), 8.08(2 \mathrm{H}, \mathrm{d}, J=8 \mathrm{~Hz}) . \mathrm{IR}(\mathrm{KBr}): 1720 \mathrm{~cm}^{-1}$. A solution of $1 \mathrm{~N} \mathrm{NaOH}(4 \mathrm{ml})$ was added to a solution of $25 \mathrm{~b}(90 \mathrm{mg}, 0.26 \mathrm{mmol})$ in $20 \mathrm{ml}$ of methanol, and the mixture was stirred for $12 \mathrm{~h}$. After acidification with $1 \mathrm{~N}$ hydrochloric acid, the mixture was extracted with AcOEt. The organic layer was dried over $\mathrm{Na}_{2} \mathrm{SO}_{4}$ and evaporated. The residue was recrystallized from AcOEt $/ n$-hexane to give 25a (67\%). 25a: color less prisms (AcOEt/n-hexane), mp 190-191 ${ }^{\circ} \mathrm{C} .{ }^{1} \mathrm{H}-\mathrm{NMR}\left(\mathrm{CD}_{3} \mathrm{OD}\right) \delta$ : $0.95(6 \mathrm{H}, \mathrm{s}), 1.42(2 \mathrm{H}, \mathrm{m}), 1.58(2 \mathrm{H}, \mathrm{m}), 1.60(3 \mathrm{H}, \mathrm{s}), 2.00(2 \mathrm{H}, \mathrm{m}), 3.38$ $(3 \mathrm{H}, \mathrm{s}), 5.71(1 \mathrm{H}, \mathrm{d}, J=15.5 \mathrm{~Hz}), 7.34(1 \mathrm{H}, \mathrm{d}, J=15.5 \mathrm{~Hz}), 7.38(\mathrm{~d}, 2 \mathrm{H}$, $J=8 \mathrm{~Hz}), 8.09(2 \mathrm{H}, \mathrm{d}, J=8 \mathrm{~Hz})$. IR (KBr): $1710,1635 \mathrm{~cm}^{-1}$. Anal. Calcd for $\mathrm{C}_{20} \mathrm{H}_{25} \mathrm{NO}_{3}$ : $\mathrm{C}, 73.37 ; \mathrm{H}, 7.70 ; \mathrm{N}, 4.28$. Found: C, 73.56; H, 7.84 $\mathrm{N}, 4.15$.

4-[N-[2-(2,6,6-Trimethyl-1-cyclohexen-1-yl)ethenyl]carbamoyl]benzoic Acid (26a) $\mathrm{NaH}(60 \%, 45 \mathrm{mg}, 1.12 \mathrm{mmol})$ was added to a solution of $15(200 \mathrm{mg}, 0.86 \mathrm{mmol})$ in $10 \mathrm{ml}$ of dry DMF at $0^{\circ} \mathrm{C}$. A solution of terephthalic acid monomethyl ester chloride $(188 \mathrm{mg}, 0.95 \mathrm{mmol})$ in $10 \mathrm{ml}$ of dry benzene was added to the mixture, and the whole was stirred at room temperature for $1 \mathrm{~h}$. After removal of the solvent, the residue was poured into AcOEt and water. The organic layer was dried over $\mathrm{Na}_{2} \mathrm{SO}_{4}$ and evaporated. The crude mixture was chromatographed on silica gel to give methyl 4-[N-methoxycarbonyl- $N$-[2-(2,6,6-trimethyl-1cyclohexen-1-yl)ethenyl]carbamoyl]benzoate $\left(89 \%, \mathrm{mp} 74-75.5^{\circ} \mathrm{C}\right)$. The diacylated compound $(240 \mathrm{mg}, 0.62 \mathrm{mmol})$ and $\mathrm{Lil} \cdot 2 \mathrm{H}_{2} \mathrm{O}(500 \mathrm{mg}$, $2.7 \mathrm{mmol}$ ) were dissolved in $10 \mathrm{ml}$ of $\mathrm{DMF}$, and the mixture was heated at reflux for $3 \mathrm{~h}$. After removal of the solvent under vacuum, the residue was poured into $30 \mathrm{ml}$ of $0.1 \mathrm{~N}$ hydrochloric acid, and extracted with AcOEt. The organic layer was washed with brine and dried over $\mathrm{Na}_{2} \mathrm{SO}_{4}$. After evaporation, the residue was chromatographed on silica gel to give 26b (89\%). 26b: colorless needles (AcOEt/n-hexane), mp 191- $192^{\circ} \mathrm{C} .{ }^{1} \mathrm{H}-\mathrm{NMR}\left(\mathrm{CDCl}_{3}\right) \delta: 0.98(6 \mathrm{H}, \mathrm{s}), 1.47(2 \mathrm{H}, \mathrm{m}), 1.62(2 \mathrm{H}$, $\mathrm{m}), 1.74(3 \mathrm{H}, \mathrm{s}), 2.00(2 \mathrm{H}, \mathrm{m}), 3.95(3 \mathrm{H}, \mathrm{s}), 5.81(1 \mathrm{H}, \mathrm{d}, J=15 \mathrm{~Hz})$, $6.92(1 \mathrm{H}, \mathrm{dd}, J=12,15 \mathrm{~Hz}), 7.90(2 \mathrm{H}, \mathrm{d}, J=8 \mathrm{~Hz}), 8.00(1 \mathrm{H}, \mathrm{d}, J=$ $12 \mathrm{~Hz}), 8.10(2 \mathrm{H}, \mathrm{d}, J=8 \mathrm{~Hz})$. IR $(\mathrm{KBr}): 1715,1610 \mathrm{~cm}^{-1}$. Anal. Calcd for $\mathrm{C}_{20} \mathrm{H}_{25} \mathrm{NO}_{3}$ : C, 73.37; H, 7.70; N, 4.28. Found: C, 73.41; H, 7.67; $\mathrm{N}$, 4.31. A solution of $2 \mathrm{~N} \mathrm{NaOH}(4 \mathrm{ml})$ was added to a solution of $26 \mathbf{b}$ (100 mg, $0.31 \mathrm{mmol}$ ) in $20 \mathrm{ml}$ of methanol, and the mixture was stirred for $12 \mathrm{~h}$. The mixture was poured into $1 \mathrm{~N}$ hydrochloric acid, and extracted with AcOEt. The organic layer was dried over $\mathrm{Na}_{2} \mathrm{SO}_{4}$ and evaporated. The residue was recrystallized from AcOEt $/ n$-hexane to give 26a $(72 \%)$. 26a: colorless prisms (AcOEt $/ n$-hexane), mp $227-$ $228.5^{\circ} \mathrm{C} .{ }^{1} \mathrm{H}-\mathrm{NMR}\left(\mathrm{CD}_{3} \mathrm{OD}\right) \delta: 1.03(6 \mathrm{H}, \mathrm{s}), 1.51(2 \mathrm{H}, \mathrm{m}), 1.65(2 \mathrm{H}, \mathrm{m})$, $1.78(3 \mathrm{H}, \mathrm{s}), 2.03(2 \mathrm{H}, \mathrm{m}), 6.04(1 \mathrm{H}, \mathrm{d}, J=15 \mathrm{~Hz}), 6.85(1 \mathrm{H}, \mathrm{d}, J=$ $15 \mathrm{~Hz}), 7.99(2 \mathrm{H}, \mathrm{d}, J=8 \mathrm{~Hz}), 8.12(2 \mathrm{H}, \mathrm{d}, J=8 \mathrm{~Hz})$. Anal. Calcd for $\mathrm{C}_{19} \mathrm{H}_{23} \mathrm{NO}_{3}: \mathrm{C}, 72.82 ; \mathrm{H}, 7.40 ; \mathrm{N}, 4.47$. Found: $\mathrm{C}, 72.99 ; \mathrm{H}, 7.37 ; \mathrm{N}$,
4.44

4-[N-Methyl- $N$-[2-(2,6,6-trimethyl-1-cyclohexen-1-yl)ethenyl]carbamoyl]benzoic Acid (27) $\mathrm{NaH}(60 \%, 10.7 \mathrm{mg}, 0.27 \mathrm{mmol})$ was added to a solution of $26 \mathrm{a}(80 \mathrm{mg}, 0.25 \mathrm{mmol})$ in $10 \mathrm{ml}$ of dry DMF at $0{ }^{\circ} \mathrm{C}$. After $30 \mathrm{~min}, 2 \mathrm{ml}$ of methyl iodide was added and the mixture was stirred for $1 \mathrm{~h}$. After removal of the solvent and excess methyl iodide, the residue was poured into water, and extracted with AcOEt. The organic layer was dried over $\mathrm{Na}_{2} \mathrm{SO}_{4}$, and evaporated to give 27 as a colorless oil. 27: ${ }^{1} \mathrm{H}-\mathrm{NMR}\left(\mathrm{CDCl}_{3}\right) \delta: 0.91(6 \mathrm{H}, \mathrm{s}), 1.41(2 \mathrm{H}, \mathrm{m}), 1.49$ $(2 \mathrm{H}, \mathrm{m}), 1.51(3 \mathrm{H}, \mathrm{s}), 1.86(2 \mathrm{H}, \mathrm{m}), 3.10(0.5 \mathrm{H}, \mathrm{br} \mathrm{s}), 3.32(2.5 \mathrm{H}, \mathrm{s}), 3.90$ $(3 \mathrm{H}, \mathrm{s}), 5.51(0.8 \mathrm{H}, \mathrm{d}, J=15 \mathrm{~Hz}), 5.55(0.2 \mathrm{H}, \mathrm{br}), 6.25(0.8 \mathrm{H}, \mathrm{d}, J=$ $15 \mathrm{~Hz}), 7.36(0.2 \mathrm{H}, \mathrm{br}), 7.52(2 \mathrm{H}, \mathrm{d}, J=8 \mathrm{~Hz}), 8.07(2 \mathrm{H}, \mathrm{d}, J=8 \mathrm{~Hz})$.

\section{References and Notes}

1) M. B. Sporn, A. B. Roberts (eds.) "The Retinoids," 2nd ed., Raven Press, New York, 1993; M. I. Dawson, W. H. Okamura (eds.) "Chemistry and Biology of Synthetic Retinoids," CRC Press, Boca Raton, FL, 1990

2) M. B. Sporn, A. B. Roberts, N. S. Roche, H. Kagechika, K. Shudo, J. Am. Acad. Derm., 15, 756 (1986).

3) C. Tickel, B. Alberts, L. Wolpert , J. Lee, Nature (London), 296, 564 (1982); C. Thaller, G. Eichele, ibid., 327, 625 (1987); N. Wanek, D. M. Gaudiner, K. Muneoka, S. V. Bryant, ibid., 350, 81 (1991); S. Noji, T. Nohno, E. Koyama, K. Muto, K. Ohyama, Y. Aoki, K. Tamura, K. Ohsugi, H. Ide, S. Taniguchi, T. Saito, ibid., 350, 83 (1991).

4) M. Petkovich, N. J. Brand, A. Krust, P. Chambon, Nature (London), 330, 444 (1987); V. Giguere, E. S. Ong, P. Segui, R. M Evans, ibid., 330, 624 (1987); N. Brand, M. Petkovich, A. Kurst, P. Chambon, H. de The, A. Marchio, P. Tiollais, A. Dejean, ibid., 332, 850 (1988); A. Kurst, P. Kastner, M. Petkovich, A. Zelent, P Chambon, Proc. Natl. Acad. Sci. U.S.A., 86, 5310 (1989).

5) Y. Hashimoto, H. Kagechika, E. Kawachi, K. Shudo, Jpn. J. Cancer Res., 79, 473 (1988); Y. Hashimoto, M. Petkovich, M. B. Gaub, H. Kagechika, K. Shudo, P. Chambon, Mol. Endocrinol., 3 1046 (1989)

6) R. Evans, Science, 240, 889 (1988); M. Beato, Cell, 56, 335 (1989); B. O'Malley, Mol. Endocrinol., 9, 2811 (1990).

7) Y. Hashimoto, K. Shudo, Cell Biol. Rev., 25, 209 (1991).

8) D. J. Mangelsdorf, E. S. Ong, J. A. Dyck, R. M. Evans, Nature (London), 345, 224 (1990); R. A. Heyman, D. J. Mangelsdorf, J. A. Dyck, R. B. Stein, G. Eichele, R. M. Evans, C. Thaller, Cell, 68, 397 (1992).

9) M. Huang, Y. Ye, S. Chen, J. Chai, J. Lu, L. Zhoa, L. Gu, Z. Wang, Blood, 72, 567 (1988); S. Castagne, C. Chomienne, M. T. Daniel, P. Ballerni, R. Berger, P. Fenaux, L. Dogos, ibid, 76, 1704 (1990).

10) W. J. Cunliffe, A. J. Miller (eds.), "Retinoid Therapy," MTP Press Limited, Lancaster, 1984

11) K. Shudo, H. Kagechika, Adv. Drug Res., 24, 81 (1993).

12) H. Kagechika, E. Kawachi, Y. Hashimoto, K. Shudo, Chem. Pharm. Bull., 32, 4209 (1984).

13) H. Kagechika, E. Kawachi, Y. Hashimoto, K. Shudo, Chem. Pharm. Bull., 34, 2275 (1986).

14) H. Kagechika, E. Kawachi, Y. Hashimoto, T. Himi, K. Shudo, J. Med. Chem., 31, 2181 (1988).

15) Y. Hashimoto, H. Kagechika, K. Shudo, Biochem. Biophys. Res. Commun., 166, 1300 (1990); Y. Hashimoto, Cell Struct. Funct., 16, 113 (1991).

16) M. Crettaz A. Baron, G. Siegenthaler, W. Hunziker, Biochem. J., 272, 391 (1990); G. Graupner, G. Malle, J. Maignan, G. Lang, M. Pruniéras, M. Pfahl, Biochem. Biophys. Res. Commun., 179, 1554 (1991); C. Delescluse, M. T. Cavey, B. Martin, B. A. Bernard, U. Reichert, J. Maignan, M. Darmon, B. Shroot, Mol. Pharmacol., 40, 556 (1991).

17) J. M. Lehmann, L. Jong, A. Fanjul, J. F. Cameron, X. P. Lu, P. Haefner, M. I. Dawson, M. Pfahl, Science, 258, 1944 (1992).

18) Y. Ishibashi, "Book of Abstracts, 18th World Congress of Dermatology," New York, 1992, p. 101A.

19) H. Kagechika, T. Himi, E. Kawachi, Y. Hashimoto, K. Shudo, J. Med. Chem., 32, 2292 (1989).

20) Y Toriumi, A. Kasuya, A. Itai, J. Org. Chem., 55, 259 (1990).

21) M. B. Smith, Org. Prep. Proc. Int., 22, 315 (1990).

22) M. Petrzika, J. I. Grayson, Synthesis, 1981, 768. 
23) W. Oppolzer, W. Fröstl, Helv. Chim. Acta, 58, 587, 590 (1975); W. Oppolzer, W. Fröstl, H. P. Weber, Helv. Chim. Acta, 58, 593 (1975); W. Oppolzer, E. Flaskamp, Helv. Chim. Acta, 60, 204 (1977); W. Oppolzer, Angew. Chem., Int. Ed. Engl., 16, 10 (1977).

24) A. L. Campbell, G. R. Lenz, Synthesis, 1987, 421.

25) W. Oppolzer, L. Bieber, E. Francotte, Tetrahedron Lett., 1979, 4537.

26) L. Berthon, D. Uguen, Tetrahedron Lett., 33, 3975 (1985).

27) J. C. Estévez, M. C. Villaverde, R. J. Estévez, L. Castedo, Syn. Commun., 23, 2489 (1993).

28) C. Palomo, J. M. Aizpurua, M. Legido, J. P. Picard, J. Dunogues, T. Constantieux, Tetrahedron Lett., 33, 3903 (1992).

29) A. Couture, E. Deniau, P. Grandclaudon, Tetrahedron Lett., 34, 1479 (1993).

30) L. E. Overman, G. F. Taylor, C. B. Petty, P. J. Jessup, J. Org. Chem., 43, 2164 (1978); P. J. Jessup, C. B. Petty, J. Roos, L. E. Overman, "Organic Syntheses," Coll. Vol. VI, ed. by W. E. Noland, John Wiley and Sons, Inc., New York, 1988, p. 95.

31) In this paper, for convenience, we defined trans-amide as a conformer whose proton or methyl on amide nitrogen is located opposite to the amide carbonyl, and cis-amide as a conformer in which they are the same side of the amide bond.

32) A. Itai, Y. Toriumi, N. Tomioka, H. Kagechika, I. Azumaya, K. Shudo, Tetrahedron Lett., 30, 6177 (1989).

33) A. Itai, Y. Toriumi, S. Saito, H. Kagechika, K. Shudo, J. Am. Chem. Soc., 114, 10649 (1992).

34) S. J. Collins, R. C. Gallo, R. E. Gallagher, Nature (London), 270, 347 (1977).

35) H. P. Koeffler, Blood, 62, 709 (1983).

36) S. J. Collins, F. W. Ruscetti, R. E, Gallagher, R. C. Gallo, J. Exp Med., 149, 969 (1979).

37) Y. Matsusima, E. Kawachi, H. Tanaka, H. Kagechika, Y. Hashimoto, K. Shudo, Biochem. Biophys. Res. Commun., 189, 1136 (1992).

38) L. Jong, J. M. Lehmann, P. D. Hobbs, E. Harlev, J. C. Huffman, M. Pfahl, M. I. Dawson, J. Med. Chem., 36, 2605 (1993).

39) P. C. Guha, D. K. Sankaran, "Organic Syntheses," Coll. Vol. III, ed. by E. C. Horning, John Wiley and Sons, Inc., New York, 1955, p. 623 . 